\title{
Ép és mozgásukban korlátozott kajakos sportolók biomechanikai mozgáselemzése és összehasonlító vizsgálata
}

\author{
Kertészné Német Bernadett ${ }^{1}$ - Terebessy Tamás dr. ${ }^{2}$ - Bejek Zoltán dr. ${ }^{2}$ \\ ${ }^{1}$ Semmelweis Egyetem, Általános Orvostudományi Kar, Doktori Iskola, Budapest \\ ${ }^{2}$ Semmelweis Egyetem, Általános Orvostudományi Kar, Ortopédiai Klinika, Budapest
}

\begin{abstract}
Bevezetés: A teljes test összerendezett mozgása mellett a kajak-kenu összehangolt kivitelezést és nagy teljesítmény leadását igénylő sport. Az evezőt mozgató, speciális technikával dolgozó felső végtag munkáját a gerinc flexiós-extenziós, illetve rotációs mozgása segíti. A törzs mozgása áttevődik az alsó végtagokra, melyek az alternáló, flexiós-extenziós mozgás mellett fontos támasztó funkciót látnak el. Ebből következőleg a sportolás közben a teljes test egy jól koordinált kinetikai láncot alkot.

Célkitüzés: Célunk az ép és a sérült sportolók mozgásának komolyabb megismerése és összehasonlítása volt.

Módszer: A vizsgálat során 13 mozgássérült elit sportoló $(\mathrm{n}=13)( \pm 18 / \pm 40$ éves, $\pm 164 \mathrm{~cm} / \pm 194 \mathrm{~cm}$ magas, \pm 74 $\mathrm{kg} / \pm 93 \mathrm{~kg}$ testsúlyú) 11 ép elit sportoló $(\mathrm{n}=1 \mathrm{l})( \pm 18 / \pm 40$ éves, $\pm 172 \mathrm{~cm} / \pm 197 \mathrm{~cm}$ magas, $\pm 72 \mathrm{~kg} / \pm 96 \mathrm{~kg}$ testsúlyú), valamint 9 ép sportoló, akikból a mozgássérültséget imitáló csoportot hoztuk létre $(\mathrm{n}=9)( \pm 8 / 40, \pm 172 \mathrm{~cm}$ $/ 197 \mathrm{~cm}$ magas, $\pm 72 \mathrm{~kg} / 96 \mathrm{~kg}$ testsúlyú) vett részt a mérésben. Méréseinkhez Vicon 3D-kamerarendszert, felületi EMG-eszközt és Weba sportkajak-ergométert alkalmaztunk. Az adatok feldolgozásához Matlab és Excel adatkezelő programokat használtunk.

Eredmények: A mérések segítségével meg tudtuk határozni az ép sportolók mozgástartományának határértékeit, valamint hogy a sérült sportolók felső végtagi mozgástartománya (vállízület, könyökízület) szignifikáns eltérést nem mutat $(\mathrm{p} \geq 0,05)$. Míg az ízületi elmozdulásban nem, úgy a felső végtag izommunkájában szignifikáns eltérést figyeltünk meg, ép izomzat esetében is $(\mathrm{p} \leq 0.05)$. A mozgássérült sportolók térdízületi mozgásában és izommunkájában szintén szignifikáns eltérés jelentkezett az ép sportolókhoz képest, mint a törzs munkája esetén (p $\leq 0,05)$. Ugyanúgy szignifikáns eltérés volt megfigyelhető a leadott teljesítményben, a kifejtett erőben és a talptámasz használatában.

Megbeszélés: Mozgássérülés esetén, legyen az szimmetrikus vagy aszimmetrikus, a talptámaszt a sportoló nem képes megfelelően kihasználni, ennek következtében szignifikáns eltérés tapasztalható a kajakozómozgásukban az ép sportolókhoz képest.
\end{abstract}

Orv Hetil. 2019; 160(52): 2061-2066.

Kulcsszavak: kajak, parasport, biomechanika

\section{Biomechanical and functional comparison of kayaking by abled-disabled athletes}

Introduction: During kayaking, the whole body works in a perfect harmony. While the trunk is doing a rotation, flexion-extension helps to the upper limb to create a special cyclic paddle. The purpose of this study was to gain a better understanding of the physical disabled (later disabled) person's kayaking motions and to probe whether there were any significant differences between disabled and non-disabled kayakers with special focus on the use of footrest. We hypothesised significantly different ranges of motion and muscle activity in lower limbs but no significant differences in those of the upper limbs.

Aim: Our goal was to know more about the abled and disbled kayaking and compare the athlete's kayaking movements.

Method: Thirteen $(\mathrm{n}=13)$ elite disabled athletes (age range: 18-40 years, height range: 164-194 $\mathrm{cm}$, body mass range:74-93 kg), eleven $(\mathrm{n}=11)$ elite non-disabled athletes (age range: 18-40 years, height range:172-197 $\mathrm{cm}$, body mass range: $72-96 \mathrm{~kg})$ and nine $(\mathrm{n}=9)$ athletes whose movements were artificially limited to imitate disabled conditions("imitation disabled" group) (age range: 18-40 years, height range: $172-197 \mathrm{~cm}$, body mass range: $72-$ 
$96 \mathrm{~kg}$ ) were measured. Weba sport kayak ergometer, surface electromyography (EMG), and a 3-dimensional Vicon (MX T40) camera system were used to record the data, and a combined Matlab and MS Excel system was used to analyse the results.

Results: In line with our basic assumption, range of motion of the upper limbs was not significantly different between disabled athletes and non-disabled athletes $(p \geq 0.05)$. However, muscle activities were significantly different in the disabled group compared to the non-disabled group $(\mathrm{p} \leq 0.05)$. In the disabled group the knee joint and trunk motions and muscle activities were also significantly different compared to those in the non-disabled group $(\mathrm{p} \leq 0.05)$. The differences in performance force applied to both footrests and force were significant $(\mathrm{p} \leq 0.05)$.

Discussion: The assumption that shoulder and elbow ranges of motion were not significantly different in disabled athletes compared to non-disabled athletes was proven. However, muscle activities were significantly different in the disabled group. In the disabled group, knee and trunk motions and muscle activities were also significantly different compared to the non-disabled group. Significant differences were found in performance, force and footrest use. Our results proved our assumption that motions and muscle activities of disabled and non-disabled athletes were significantly different.

Keywords: kayak, disabled sport, biomechanics

Kertészné Német B, Terebessy T, Bejek Z. [Biomechanical and functional comparison of kayaking by abled-disabled athletes]. Orv Hetil. 2019; 160(52): 2061-2066.

(Beérkezett: 2019. március 23.; elfogadva: 2019. július 20.)

\section{Rövidítések}

$\mathrm{EMG}=$ elektromiográfia $\mathrm{KL}=($ kayak cluster $)$ kajakkategória

A világon egyre növekvő számban vesznek részt a kajaksportágban mozgássérültek is, ami magyar vonatkozásban is elmondható. A sportág népszerűségét és fejlődési dinamikáját jelzi, hogy a 2016-os paralimpián már hivatalos versenyszámként volt jelen. A mozgásukban megváltozott sportolók esetén, sérültségükből adódóan, az egészséges sportolókra jellemző kinetikai lánc sérül, illetve a mozgássorba kompenzatorikus elemek épülnek be $[1,2]$. Mindez természetesen függ a kieső mozgásszervi funkció helyétől, mértékétől és jellegétől. A különböző mozgásszervi sérülések, valamint kompenzációs mozgásminták különböző teljesítményt és mozgáskivitelezést eredményeznek. Ebből következően a más és más típusú sérültséggel rendelkező sportolók teljesítménye is különböző. A mozgássérültsport (parasport) célja az esélyegyenlőség megteremtése a különböző mértékben megváltozott képességű sportolók számára [3]. Ebből kifolyólag a para kajak-kenu sportban a Nemzetközi Para Kajak-Kenu Szövetség három versenyzési kategóriát hozott létre, melyeket a Nemzetközi Paralimpiai Bizottság is elfogadott. Ennek megfelelően a sportolók három kategóriában vehetnek részt a versenyeken: KLl - a minimális funkcióval rendelkező sportolók, KL2 - a közepes funkciókkal rendelkező sportolók, KL3 - a legnagyobb stabilitással rendelkező sportolók csoportja [4].

A szakirodalomban viszonylag kevesen foglalkoznak a para kajak-kenu mechanikai vizsgálatával. Munkánkon keresztül szeretnénk jobban megismerni a sportág mozgásmechanizmusát mozgáskorlátozottság esetén. Kutatásunkban az ép sportolók mozgásfunkcióinak határértékeit kívántuk meghatározni, majd megmérve a mozgá- sukban korlátozott sportolók mozgásfunkcióit, meghatározhattuk, hogy a sérülések valóban szignifikánsan eltérő mozgásfunkciót eredményeznek, és ezek mely területeken tapasztalhatók. Célunk az ép sportolók mozgásának modellezése volt [5], melyhez Weba sportkajakergométert, felületi EMG-t, valamint Vicon MX T40 3D-kamerarendszert használtunk. Az ép sportolók ízületi mozgástartományának és izommúködésének mérésével és meghatározásával kiindulási alapot teremthettünk a sérült sportolók mozgásának vizsgálatához [6-9]. További célunk volt előidézni ép sportolók esetében a sérült sportolókéhoz hasonló funkció hiányából fakadó korlátozott mozgásmintát, ezzel vizsgálva azt, hogy milyen mértékben változik ízületeiknek a mozgási lehetősége, illetve izommúködésük. A vizsgálat részét képezte a felső végtag mozgásának és izommúködésének vizsgálata is, annak ellenére, hogy mindegyik csoport esetében épegészséges felső végtag volt jellemző.

Feltételezésünk volt, hogy a sérültek alsó végtagi, valamint törzsi érintettségének következtében a felső végtag szabad mozgása és izommunkája lehetséges, így abban szignifikáns különbség nem várható az épekhez képest [2, 10-14]. További feltételezésünk volt, hogy szignifikáns különbség mutatkozik a törzs mozgástartományában, valamint izommunkájában, és az alsó végtag ízületi mozgásában és izommunkájában. Az eltérő mozgástartomány és izommúködés következtében feltételeztük, hogy a mozgás során kifejtett erőben és teljesítményben szintén szignifikáns eltérés várható.

\section{Anyag és módszer}

A vizsgálat során 13 mozgássérült elit sportoló (1. táblázat $)(\mathrm{n}=13)( \pm 18 / \pm 40$ éves, $\pm 164 \mathrm{~cm} / \pm 194 \mathrm{~cm}$ magas, $\pm 74 \mathrm{~kg} / \pm 93 \mathrm{~kg}$ testsúlyú $), 11$ ép elit sportoló $(\mathrm{n}=11)$ 
1. táblázat |A megváltozott képességű sportolók sérüléseinek összefoglalása

\begin{tabular}{|c|c|}
\hline Sportoló & Sérülés \\
\hline 1. & $\begin{array}{l}\text { Progresszív krónikus polyarthritis alsó végtagi mozgás- } \\
\text { korlátozottsággal }\end{array}$ \\
\hline 2. & $\begin{array}{l}\text { Perifériás artériás zavar alsó végtagi izommúködési } \\
\text { zavarral }\end{array}$ \\
\hline 3. & Összetett traumás sérülés alsó végtagi túlsúllyal \\
\hline 4. & Heine-Medin-kór \\
\hline 5 . & T11 komplett laesio \\
\hline 6. & Pes equinovarus \\
\hline 7. & C6 inkomplett laesio \\
\hline 8. & Ll komplett laesio \\
\hline 9. & Spina bifida + amputáció \\
\hline 10. & T12-L1 komplett laesio \\
\hline 11. & T12 komplett laesio \\
\hline 12. & Cerebralis paresis \\
\hline 13. & Hemofília alsó végtagi ízületi diszfunkcióval \\
\hline
\end{tabular}

$( \pm 18 / \pm 40$ éves, $\pm 172 \mathrm{~cm} / \pm 197 \mathrm{~cm}$ magas, $\pm 72 \mathrm{~kg} / \pm 96$ kg testsúlyú), valamint 9 ép sportoló, akikboól a mozgássérültséget imitáló csoportot hoztuk létre $(\mathrm{n}=9)$ $( \pm 18 / 40, \pm 172 \mathrm{~cm} / 197 \mathrm{~cm}$ magas, $\pm 72 \mathrm{~kg} / 96 \mathrm{~kg}$ testsúlyú ) vett részt a mérésben.

Kutatásunkhoz a Semmelweis Egyetem Ortopédiai Klinikájának megfelelő helyszínnel és eszköztárral rendelkező biomechanikai laboratóriuma állt rendelkezésre, amihez további segítséget a Testnevelés- és Sporttudományi Egyetem kajak-kenu szakága és a Honvéd Sportegyesület szakedzője biztosított. Munkánk további pontosításához az ép sportolók közül létrehoztunk egy mozgássérültséget utánzó csoportot (a későbbiekben: imitált csoport), akiknek szintén lemértük a mozgásfunkcióit sérülést előidézett állapotban ( 1 . ábra). A mérések során saját készítésû speciális beülőmodelleket (2. és 3. ábra) és a megváltozott képességú sportolók által is használt kiegészítóket alkalmaztunk.

$\mathrm{Az}$ imitált csoport vizsgálatával munkánk pontosságát kívántuk igazolni. Az eredményesség és pontosság céljából homogén csoport vizsgálatára törekedtünk, melynek tagjait férfi kajakosok alkották. A sportoló teljes körú tájékoztatásban részesült a vizsgálatot illetóen, 145281/2019/EKU ügyiratszámú dokumentum jóváhagyásával.

A sportolók anamnézisének részét képezte az antropometriai adatok rögzítése: életkor, testsúly, testmagasság, az alsó végtagok hossza (spina iliaca anterior superior-tuberositas tibiae-malleolus medialis távolság), a tibia condylus medialis-lateralis közötti távolság, a malleolus medialis-lateralis közötti távolság, míg a felső végtagon a jobb és bal oldalon az acromion-axilla távolság, a könyökszélesség-humerus epicondylus medialis-lateralis közötti távolság, a processus styloideus radii-processus styloideus ulnae közötti távolság, és a kézen a 3. metacarpus középső harmadában mért vastagság [2].
Ép sportolók esetében elegendő volt a fent leírt adatok felvétele. A megváltozott képességú sportolók esetében rögzítettük a sérülést, annak idejét, szükség esetén a mútéti eljárást és a vizsgálatkori funkcióképességet: ehhez a Nemzetközi Para Kajak-Kenu Szövetség által hitelesen használt vizsgálati lapot használtuk fel, mely a versenyzési kategorizálóvizsgálat alkalmával is használatos [4].

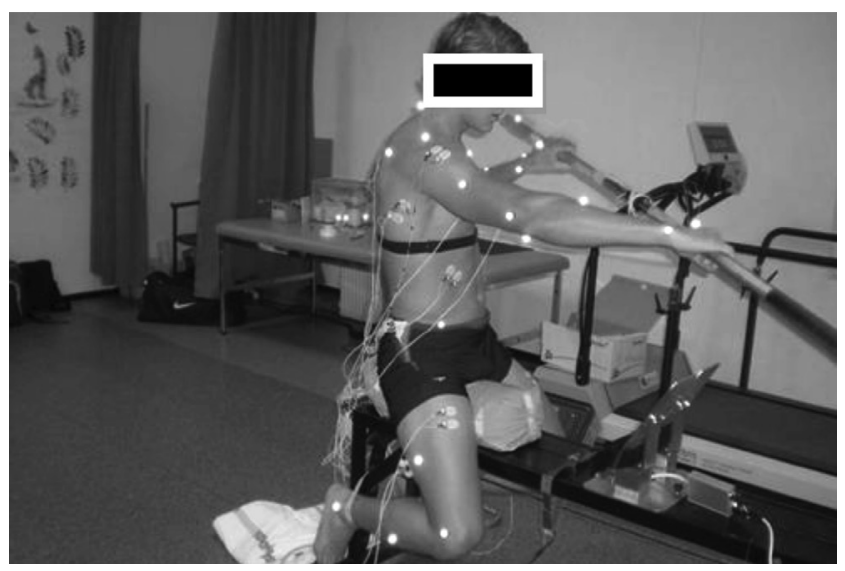

1. ábra | Ép sportoló sérülést imitáló helyzetben történő mérése

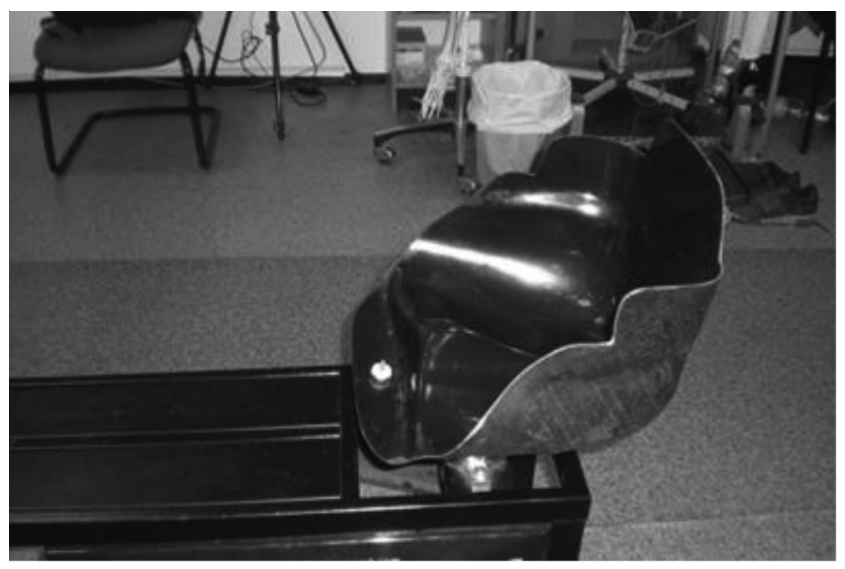

2. ábra | Speciális beülőmodul

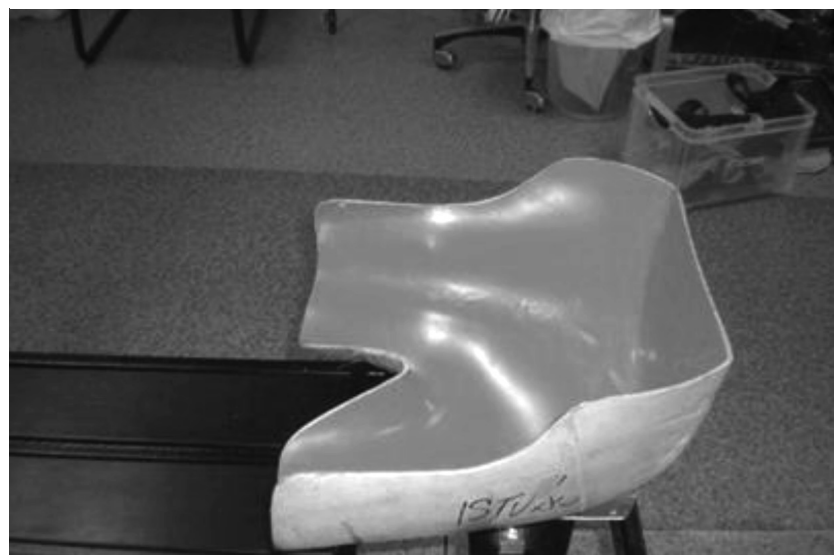

3. ábra $\quad$ Speciális beülómodul 
2. táblázat |A mozgás szempontjából legmeghatározóbb izmok, ízületek és a talptámaszhasználat minimum-maximum értékeinek összefoglalása

\begin{tabular}{|c|c|c|c|c|}
\hline & $\begin{array}{l}\text { 1. Mozgássérült } \\
\text { sportolók }\end{array}$ & & $\begin{array}{l}\text { 2. Ép } \\
\text { sportolók }\end{array}$ & \\
\hline Az izmok múködése (volt) & Minimum 1 & Maximum 1 & Maximum 2 & Minimum 2 \\
\hline Jobb musculus deltoideus & 0,0649737 & 4,210399486 & 4,665742656 & 0,64544969 \\
\hline Jobb musculus latissimus dorsi & 0,2664981 & 3,015601763 & 6,036495877 & 0,47452185 \\
\hline Jobb musculus pectoralis major & 0,0706558 & 1,203953053 & 2,815497069 & 0,21066927 \\
\hline Jobb musculus biceps brachii & 0,1490737 & 2,039204397 & 5,457707555 & 0,29083513 \\
\hline Jobb musculus obliquus externus abdominis & 0,0370852 & 3,631129283 & 3,84236203 & 0,29226708 \\
\hline Jobb musculus rectus femoris & 0,031642 & 0,073092143 & 0,611192986 & 0,08613611 \\
\hline Jobb musculus biceps femoris & 0,0062646 & 0,080883908 & 0,159777748 & 0,04269346 \\
\hline Bal musculus deltoideus & 0,0206577 & 1,593485667 & 4,661012515 & 0,28323154 \\
\hline Bal musculus latissimus & 0,0264739 & 1,236054468 & 5,477268605 & 0,43643523 \\
\hline Bal musculus pectoralis major & 0,0493882 & 1,162977448 & 1,693197947 & 0,16224957 \\
\hline Bal musculus biceps brachii & 0,0017341 & 0,502310237 & 4,515546902 & 0,23927147 \\
\hline Bal musculus obliquus externus adbominis & 0,0190498 & 0,764191923 & 3,538095715 & 0,28453145 \\
\hline Bal musculus rectus femoris & 0,003109 & 0,054053792 & 0,762157001 & 0,14212346 \\
\hline Bal musculus biceps femoris & 0,0106907 & 0,151221497 & 0,249579678 & 0,04870467 \\
\hline Ízületi mozgás (fok) & Minimum 1 & Maximum 1 & Maximum 2 & Minimum 2 \\
\hline A jobb könyök flexiója & 82,141377 & 142,9146023 & 143,4649576 & 82,5054139 \\
\hline A bal könyök flexiója & 80,781717 & 142,3674876 & 151,349443 & 80,1972783 \\
\hline A jobb váll flexiója & 73,28502 & 92,25629838 & 96,85065235 & 74,5236242 \\
\hline A bal váll flexiója & 70,410522 & 96,92792635 & 97,16258848 & 70,5388301 \\
\hline Törzsrotáció & 0,1151537 & 60,34349 & 60,32294202 & 9,0943995 \\
\hline A jobb térd flexiója & 128,91811 & 148,9252507 & 150,8562455 & 120,2941 \\
\hline \multirow[t]{2}{*}{ A bal térd flexiója } & 119,93564 & 143,9789864 & 146,292793 & 126,784012 \\
\hline & Minimum 1 & Maximum 1 & Maximum 2 & Minimum 2 \\
\hline A bal talptámasz értéke (newton) & 17,148429 & 176,7987786 & 378,9969455 & 37,2396843 \\
\hline A jobb talptámasz értéke (newton) & 15,162737 & 143,2520737 & 338,0862312 & 49,6795541 \\
\hline
\end{tabular}

A fent leírt vizsgálatot követően felhelyeztük a fényvisszaverő markereket a mérésünkhöz szükséges, a Vicon-rendszer részét képező Plug-in-Gait protokoll felhasználásával a meghatározott anatómiai pontokra, kétoldalú ragasztócsík segítségével $[15,16]$. Majd megfelelő előkészülettel (szőrtelenítés, bőrfertótlenítés) felhelyeztük a felületi EMG-elektródákat, amikor a sportoló már a kajakergométeren ült. Az elektródák a mozgás szempontjából legmeghatározóbb izmokra kerültek felhelyezésre: musculus [m.] latissimus dorsi, m. deltoideus medialis, $\mathrm{m}$. pectoralis major, $\mathrm{m}$. biceps brachii, m. rectus femoris, $\mathrm{m}$. biceps femoris, m. obliquus externus abdominis $[10,11]$. Minden esetben egyenként ellenőrzésre került az elektródák megfelelő múködése, ami az adott izom maximális megfeszítésével történt.

A sportolókat felkértük (pulzusmérő óra kontrollja mellett) a bemelegítésre 50\%-os intenzitással, majd a megfelelő pulzus elérésekor 200 méteres táv leevezésére kértük őket $80 \%$-os szubmaximális intenzitással, végül levezetésként addig evezett a sportoló, míg pulzusa el nem érte a megfelelő tartományt, mely a jelenlévő szakemberek és az óra segítségével került meghatározásra, minden sportoló esetében egyénre szabottan. A mérések minden esetben orvos és szakedző jelenlétében történtek. A 200 méteres táv a hivatalos paraversenytáv alapján került meghatározásra, mely az épek esetében is hivatalos versenyszám.

Mérési kritériumaink közé tartozott, hogy a mozgásukban megváltozott képességú sportoló annak megfelelóen, hogy a későbbiekben hogy kíván versenyezni - protézisben vagy a nélkül, ortézisben vagy a nélkül -, hajtsa végre az általunk kért feladatot.

\section{Eredmény}

A kapott adatokból meghatározhattuk, hogy az adott mozgásciklusok során a mozgás szempontjából legmeghatározóbb izmok milyen maximális és minimális aktivitással múködnek, valamint a törzs és az alsó-felső végtag ízületei milyen maximális és minimális mozgástartományban mozognak mind az ép sportolók, mind a mozgássérült sportolók esetében (2. táblázat). A kapott adatokhoz viszonyítottan meg lehetett határozni, hogy a 


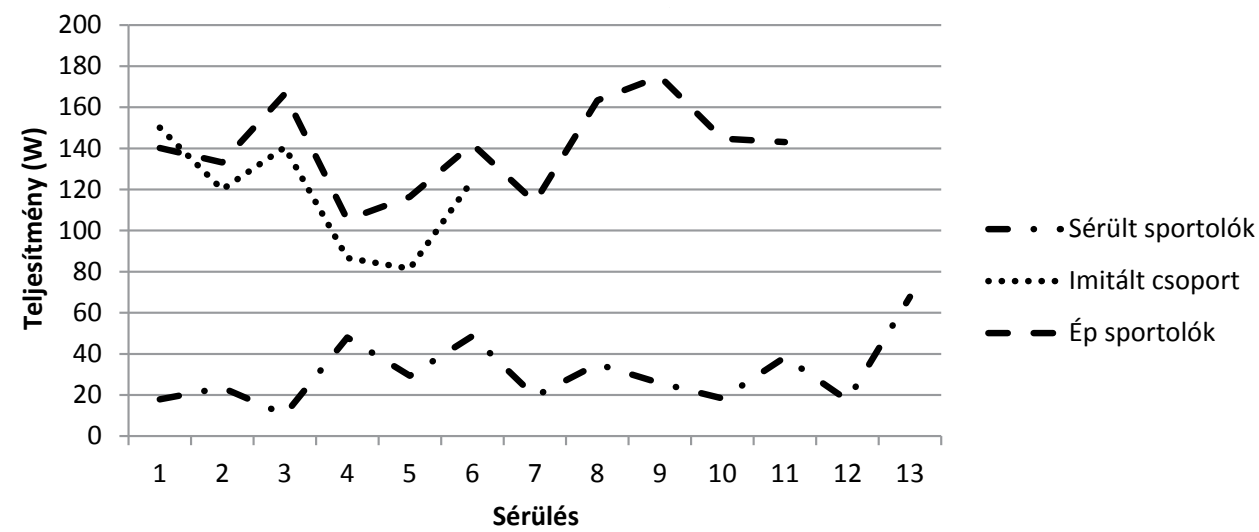

4. ábra | Elit férfi kajakosok 200 méteren leadott teljesítményének összehasonlító ábrája

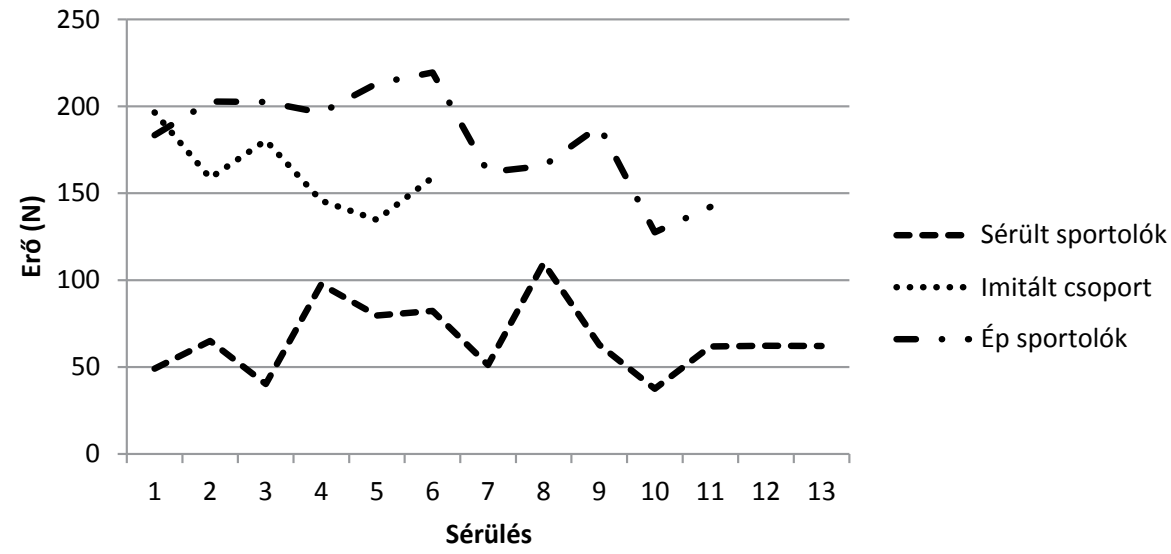

5. ábra | Elit férfi kajakosok erókifejtésének összehasonlító ábrája 200 méter kajakozás során

mozgásukban megváltozott képességú sportolók eredményei szignifikánsan vagy nem szignifikánsan térnek el az ép sportolókéhoz képest.

Vizsgálatunk során a mozgássérült sportolók felsó végtagi ízületi funkcióiban az ép sportolók ízületi elmozdulásához képest szignifikáns eltérés nem volt tapasztalható ( $\mathrm{p} \geq 0,05)$. Míg az ízületi elmozdulásban nem, úgy a felső végtag izommunkájában szignifikáns eltérést figyeltünk meg, ép izomzat esetében is $(p \leq 0,05)$. A megváltozott képességű sportolók térdízületi mozgásában és izommunkájában szintén szignifikáns eltérés jelentkezett az ép sportolókhoz képest, mint a törzs munkája esetén $(\mathrm{p} \leq 0,05)$.

Az ép sportolók mozgását korlátozva - mozgássérülést imitálva - is elvégeztük a méréseket. Ehhez speciális beülőmodulokat és eszközöket használtunk, amelyeket a mozgássérült sportolók is alkalmaznak. A mérések eredményeinek kiértékelései során minden esetben szignifikáns eltérés volt tapasztalható az épekhez képest, mind az ízületi elmozdulásban, mind az izommunkában. Az imitált állapot olyan mértékben megváltoztatta a sportolók mozgását, hogy ebben az esetben még a felső végtag ízületi mozgásában is szignifikáns eltérés volt tapasztalható.
Mind az ízületi, mind az izommúködésben jelentkezett eltérések a kifejtett erő és teljesítmény szignifikáns eltérését eredményezték (4. és 5 . ábra).

\section{Megbeszélés}

Vizsgálatunkat követően elmondhatjuk, hogy szignifikánsan eltérô ízületi és izomfunkció jellemzi a sérültek mozgását kajakozás során, ami nehezíti a megfelelő technika kivitelezését. A sérülések hatására oly mértékben megváltoznak a funkciók, hogy a kifejtett eró és teljesítmény is szignifikánsan eltér az épekhez képest a kompenzatorikus mozgások ellenére. Az eltérés oka véleményünk szerint több okból adódik. Egyrészt a sérülés okozta lecsökkent teljesítőképesség, másrészt a másodlagos kompenzálófunkciók ébredése tehető érte felelőssé. Harmadrészt pedig a tudatos, sérülésspecifikus edzésnek a következménye, melynek során a sportoló és edzője közösen a meglévő mozgásfunkciókat, képességet igyekeznek erősíteni, fejleszteni. A sérülést imitált állapot szintén jelentős változásokat eredményezett, ebben az esetben még a felső végtag ízületi mozgásában is szignifikáns eltérés volt tapasztalható. Az, hogy a korlátozott mozgás a felső végtagi funkciók szignifikáns eltérését mutatta, egyben rámutat arra is, hogy a mozgásukban 
megváltozott képességű sportolók kompenzációs mechanizmusainak kiépítéséhez, a megfelelő felső végtagi munka kivitelezéséhez idő és tudatos edzés, valamint igen nagy erőfeszítés szükséges. A szakirodalomban több helyen olvashatjuk, hogy a sportnak milyen meghatározó szerepe van a mozgásukban sérültek esetében, mind testileg, mind lelkileg. A kajakozás kiemelt szerepéről gerincsérültek esetében Bjerkefors svéd gyógytornász kutatásában olvashatunk [17]. Az általunk mért eredmények alapján nagyobb rálátásunk nyílt arra, hogy a sérülések esetében valóban szignifikáns ízületi és izommúködés, valamint teljesítményváltozás jelentkezik az épekhez képest. Az eredmények további összefüggések vizsgálatát teszik lehetővé, amely még pontosabb képet adhat a sérült sportolók mozgásáról. A kompenzációs folyamatok pontosabb megértése segít a megfelelő, személyre szabott edzésterv kifejlesztésében, ami a sportoló teljesítményének növelésében nyújthat segítséget. A kompenzációs mozgásminta és az abból fakadó túlterheltség pontos meghatározásához nagyobb esetszám vizsgálata szükséges. A parasport rohamos fejlődése figyelhető meg világszerte, ami fontossá teszi, hogy a szakirodalomban is komolyabb teret kapjon.

Anyagi támogatás: A közlemény megírása és a kutatómunka kiemelt támogatásban nem részesült. A közlemény doktori munka részét képezi.

Szerzői munkamegosztás: A hipotézisek kidolgozása: K. N. B., B. Z. A vizsgálat lefolytatása: K. N. B., B. Z., T. T. Statisztikai elemzés: K. N. B. A kézirat megszövegezése: K. N. B., B. Z.

Érdekeltségek: A szerzőknek nincsenek anyagi érdekeltségeik.

\section{Irodalom}

[1] Begon M, Colloud F, Sardain P, et al. Lower limb contribution in kayak performance modelling, simulation and analysis. Multibody Syst Dyn. 2010; 23: 387.

[2] Brown M B, Lauder M, Dyson R. Activation and contribution of trunk and leg musculature to force production during on-water sprint kayak performance. 28th International Conference on Bi- omechanics in Sports. Conference Proceedings Archive 2010; 28: 1-4. Published: 2010-08-10.

[3] Shogan, D. The social construction of disability: the impact of statistics and technology. Adapted Physical Activity Quarterly 1998; 15: 269-277.

[4] Paralympic sports: canoe. Classification in para canoe. Official website of the Paralympic Movement, IPC, Bonn. https://www. paralympic.org/canoe/classification.

[5] Illyés Á, Bejek Z, Szlávik I, et al. Three-dimensional gait analysis after unilateral cemented total hip arthroplasthy. Facta Universitatis Series: Physical Education and Sport 2006; 4: 27-34.

[6] Lovell GP, Lauder MA. Bilateral strength comparisons among injured and noninjured competitive flatwater kayakers. J Sport Rehabil. 2001; 10: 3-10.

[7] McKean MR, Burkett B. The relationship between joint range of motion, muscular strength, and race time for sub-elite flat water kayakers. J Sci Med Sport 2010; 13: 537-542.

[8] Michael JS, Rooney KB, Smith RM. The dynamics of elite paddling on a kayak simulator. J Sports Sci. 2012; 30: 661-668.

[9] Michael JS, Smith R, Rooney KB. Determinants of kayak paddling performance. Sports Biomech. 2009; 8: 167-179.

[10] Fleming N, Donne B, Fletcher D, et al. Effect of kayak ergometer elastic tension on upper limb EMG activity and 3D kinematics. J Sports Sci Med. 2012; 11: 430-437.

[11] Hibbs AE, Thompson KG, French DN, et al. Peak and average rectified EMG measures: which method of data reduction should be used for assessing core training exercises? J Electromyogr Kinesiol. 2011; 21: 102-111.

[12] Limonta E, Squadrone R, Rodano R, et al. Tridimensional kinematic analysis on a kayaking simulator: key factors to successful performance. J Sport Sci Health 2010; 1: 27-34.

[13] McDonnell LK, Hume PA, Nolte V. An observational model for biomechanical assessment of sprint kayaking technique. Sports Biomech. 2012; 11: 507-523.

[14] Nilsson JE, Rosdah HG. Contribution of leg-muscle forces to paddle force and kayak speed during maximal-effort flat-water paddling. Int J Sports Physiol Perform. 2016; 11: 22-27.

[15] Bejek Z, Paróczai R, Illyés Á, et al. Gait parameters of patients with osteoarthritis of the knee joint. Facta Universitatis Series: Physical Education and Sport 2006; 4: 9-16.

[16] Dempster WT. Space requirements of the seated operator: geometrical, kinematic, and mechanical aspects of the body with special reference to the limbs. Wright-Patterson Air Force Base, Ohio, Wright Air Development Center, 1955. Series WADC Technical Report 1995; pp. 55-159.

[17] Bjerkefors A, Thorstensson A. Effects of kayak ergometer training on motor performance in paraplegics. Int J Sports Med. 2006; 27: 824-829.

(Kertészné Német Bernadett, Budaörs, Beregszászi u. 59/1., 2040 e-mail: nemet.bernadett@gmail.com)

A cikk a Creative Commons Attribution 4.0 International License (https://creativecommons.org/licenses/by/4.0/) feltételei szerint publikált Open Access közlemény, melynek szellemében a cikk bármilyen médiumban szabadon felhasználható, megosztható és újraközölhetö, feltéve, hogy az eredeti szerző és a közlés helye, illetve a CC License linkje és az esetlegesen végrehajtott módositások feltüntetésre kerülnek. (SID_1) 